\title{
Substantiating the method of filling the goaf using the rock jam phenomenon
}

\author{
Vladimir I. Golik ${ }^{1 *}$, Niiaz G. Valiev², lurii I. Razorenov³ ${ }^{3}$ Viktor G. Lukianov, \\ Stanislav A. Maslennikov ${ }^{5}$ \\ ${ }^{1}$ North Caucasian Institute of Mining and Metallurgy (State Technological University), \\ Vladikavkaz, Russia \\ 2 Ural State Mining University, Ekaterinburg, Russia \\ ${ }^{3}$ Platov South-Russian State Polytechnic University, Novocherkassk, Russia \\ ${ }^{4}$ National Research Tomsk Polytechnic University, Tomsk, Russia \\ ${ }^{5}$ Don State Technical University (branch), Shakhty town, Rostov region, Russia \\ *e-mail: v.i.golik@mail.ru
}

\begin{abstract}
Research subject, theme, and aim center on detailing jam mechanism of discrete rock in hard rock masses and implementing its residual strength to optimize the processes of goaf filling.

Research methodology includes structural mechanics and continuum mechanics provisions application to explain and improve the methods of using the mechanism of discrete rocks residual strength implementation due to rock jam when calculating the host rock state control parameters.

Research results and scope. The idea of goaf filling during dislocated deposits underground mining is described. Information is given on the geological structure of the studied rocky ore deposit and the role of tectonic structures in the behavior of the mass during its development. The results of the research carried out on the state of the rock mass are shown and some geotechnical sites are distinguished as part of it on the basis of rock weakness feature. Some variants of host rock behavior depending on the joint blocks jam phenomenon are considered. The possibilities are substantiated of goaf filling by combining the methods of filling with insulation and stowing with hardening mixtures. The scope of the research results is recommended for solid mineral deposits underground development.

Summary. For the moment, the use of computational methods at discrete rock residual strength implementation due to rock jam through discrete rock jamming properties is a little-used factor of a goaf filling technology, which makes it possible to obtain an environmental and economic effect while ensuring the safety of mining.
\end{abstract}

Key words: rock; strength; filling; goaf; jam; control; safety.

Acknowledgements. The article presents the results of the research carried out under the project Erasmus + 574061-EPP-1-2016-1-DE-EPPKA2-CBHE-JP "Modernization of geological education in Russian and Vietnamese universities".

Introduction. A direction of goaf filling technological development is the use of discrete rock jam phenomenon and residual strength implementation.

In a number of instances, the use of rock properties makes it possible to obtain an environmental and economic effect while ensuring the safety of mining. Filling processes optimization is the aim of the present research.

Results. The geology of Ishym field is made up by the sedimentary rock of the Cambrian-Ordovician and the Devonian as well as the volcanic deposits of the Late Ordovician and the Devonian. The crucial role in the structure and the ore content of the deposit is played by the faults (fig. 1). 
Ore bodies are localized in rock of the Cambrian-Ordovician and the Middle and Upper Devonian.

Field specific jointing is the same both in the rock of the Cambrian-Ordovician and the Devonian. In the Devonian it makes up 2-4 fractures per $1 \mathrm{~m}$, and 6 in the rock of the Cambrian-Ordovician. Jock jointing increases near tectonic faults and makes up 10-19 within the line of the fault, and reaches 50 and more fractures per $1 \mathrm{~m}$ in ore bodies. The character of rock jointing distribution in at the heading sides and handing sides of the zones is almost the same. Rock jointing manifests most intensively in feather disturbances and in their vicinity.

The main factor of outcrop stability is rock jointing impact (fig. 2).

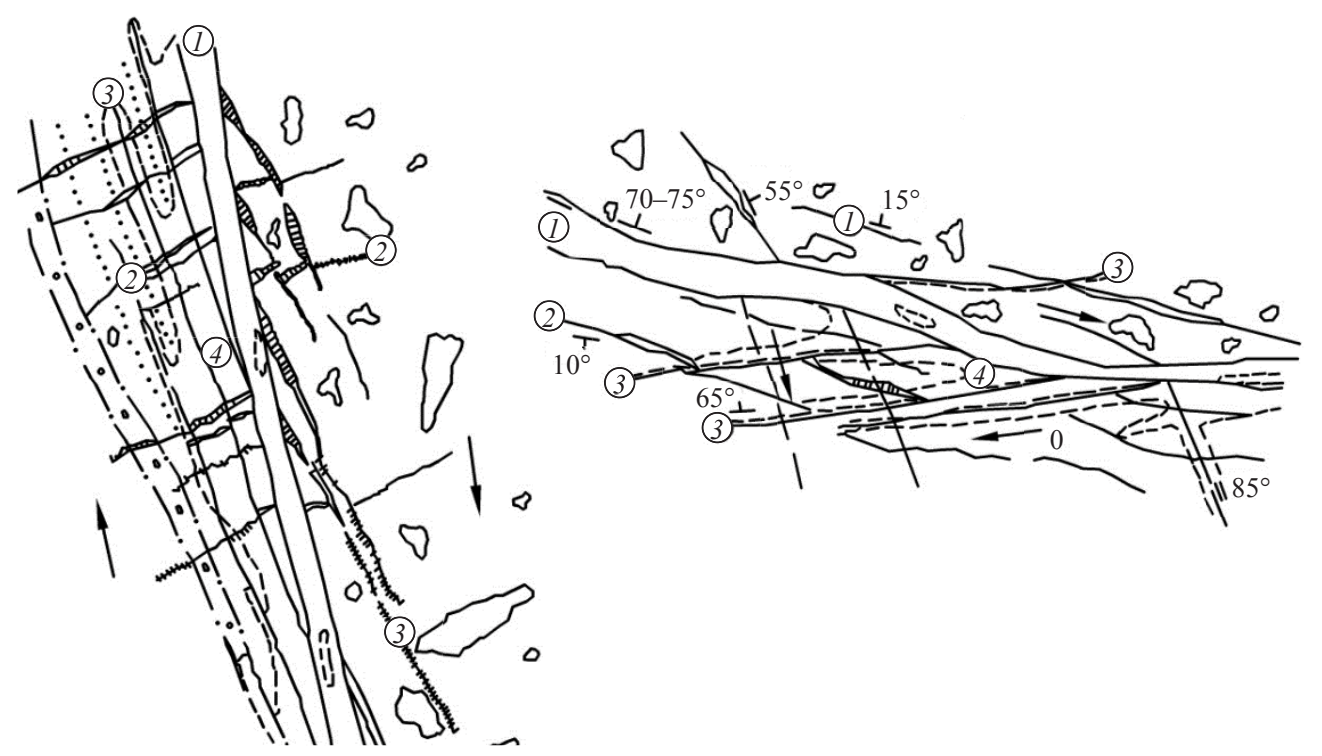

Fig. 1. Plan and cross section of fault:

1 - stratification zone; 2 -tension joint; 3 - shear fractures with gouge; 4 -metallization

Рис. 1. План и разрез разлома:

1 - зона расслоения; 2 - трещины отрыва; 3 - трещины скола с глинкой трения; 4 - оруденение

Inrush is possible at the intersection of steep and gently sloping zones interfaces, and also in the instance when a tectonic disturbance joint near the heading side is the wall of the mine working. The lateral dimensions of structure blocks can be defined according to the formulae proposed by the authors (fig. 3, 4) [1]:

when $\alpha \geq\left(90^{\circ}+\varphi\right) / 2$

$$
d_{1}=\left[\frac{2 h}{\operatorname{tg}\left(\left(90^{\circ}+\varphi\right) / 2\right)}+\frac{m}{\sin \alpha}\right] \cdot\left[2\left(\frac{10 R_{\text {compr }}^{1}}{H \gamma}-1\right)\right]^{-1} ;
$$

when $\alpha<\left(90^{\circ}+\varphi\right) / 2$

$$
d_{1}=\left[h\left(\frac{1}{\operatorname{tg}\left(\left(90^{\circ}+\varphi\right) / 2\right)}+\frac{1}{\operatorname{tg} \alpha}\right)+\frac{m}{\sin \alpha}\right] \cdot\left[2\left(\frac{10 R_{\text {compr }}^{1}}{H \varphi}-1\right)\right]^{-1},
$$

where $d_{1}$ is the lateral dimension of a structure block of rock, $\mathrm{m} ; \alpha$ - goaf inclination angle, degrees; $\varphi$ - angle of rock shear resistance, degrees; $h$ - goaf height, $m$; 
$m$ - normal width of a goaf, $\mathrm{m} ; R_{\text {compr }}^{1}-$ ultimate compressive strength of rock, $\mathrm{kg} / \mathrm{sm}^{2}$; $\gamma$-volumetric weight of rock, $\mathrm{t} / \mathrm{m}^{3} ; \mathrm{H}$ - the depth of the imposts of the natural balance arch, $\mathrm{m}$.

Integrated studies of a mass state make it possible to distinguish between some geotechnical sites within the mass (table 1).

The method of filling at rock cave-in under the ultimate arch [2]:

$$
\alpha=d_{1}\left(\frac{10 R_{\text {compr }}}{k H \gamma}-1\right),
$$

where $\alpha$ - the half-span of the arch of natural balance, $\mathrm{m} ; d_{1}$ - the lateral dimension of a joint block of rock, $\mathrm{m} ; R_{\text {compr }}$ - ultimate compressive strength, $\mathrm{kg} / \mathrm{cm}^{2} ; 10-\mathrm{kg} / \mathrm{cm}^{2}$ to $\mathrm{t} / \mathrm{m}^{2}$ conversion factor; $\gamma$ - volumetric weight of rock, $\mathrm{kg} / \mathrm{m}^{3} ; H$ - the depth of the impost from the surface, $\mathrm{m} ; k$ - safety factor.
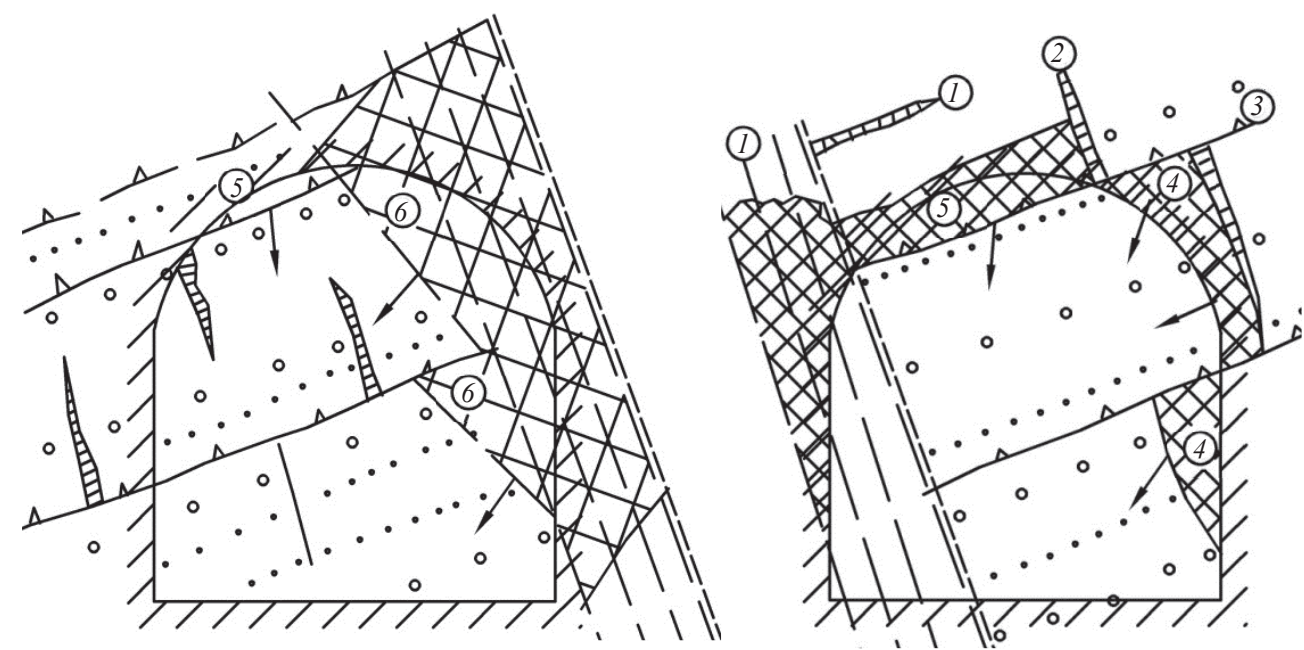

Fig. 2. The character of rock cave-in from the direction of the hanging and heading sides of the fault:

1 - fault; 2 - tension joints; 3 - layered faults; 4 - inrush along the tension joints of layered zones; 5 - inrush at layered joints; 6 -inrush at shear fracture of the fault zone

Рис. 2. Характер обрушения пород со стороны висячего и лежачего боков разлома:

1 - разлом; 2 - трещины отрыва; 3 - послойные срывы; 4 - вывалы по трещинам отрыва послойных зон;

5 - вывалы по послойным трещинам; 6 - вывалы по трещинам скола зоны разлома

Joint blocks self-jam is possible if the span of the ultimate $\operatorname{arch} B$ is bigger than the span of the cave-in zone:

$$
2 a \geq B
$$

Fig. 3 and 4 represent the cave-in zone for the following instances:

- the inclination angle of the stope is greater than the caving angle

$$
\alpha \geq \frac{90^{\circ}+\varphi}{2}
$$

- the inclination angle of the stope is less than the caving angle

$$
\alpha \leq \frac{90^{\circ}+\varphi}{2} \text {. }
$$


The span of the ultimate arch

$$
B=\frac{2 h}{\operatorname{tg}\left(\left(90^{\circ}+\varphi\right) / 2\right)}+\frac{m}{\sin \alpha},
$$

where $h$ - the height of the mine working, $\mathrm{m} ; \alpha$ - the inclination angle of the mine working, degrees; $\gamma-$ angle of shear resistance of rock, degrees $\left(45^{\circ}-50^{\circ}\right)$; $m$ - the width of the goaf, $\mathrm{m}$.

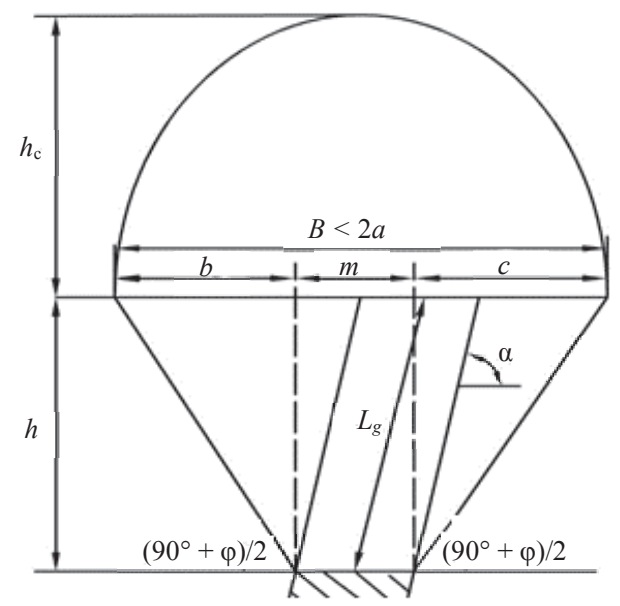

Fig. 3. Scheme for ultimate arch of balance development condition determination at steeply pitching ore body:

$L_{g}$ - ore body inclined height, $\mathrm{m} ; b$ - circle of influence of ore body hanging side, $\mathrm{m} ; c$ - circle of influence of ore body hanging side, $\mathrm{m}$

Рис. 3. Схема к определению условия образования предельного свода равновесия при крутом падении рудного тела:

$L_{g}$ - наклонная высота рудного тела, м; $b$ - зона влияния висячего бока рудного тела, м; $c-$ зона

влияния висячего бока рудного тела, м
The height of the self-jam arch $h_{a}$ under $2 a=B$ :

$$
h_{a}=\frac{a}{v},
$$

where $a$ - the half-span of the arch without the safety factor $k ; v$ - fractured rock stability factor;

$$
v=2 \frac{d_{2}}{d_{1}} \cdot \frac{R_{c o m p r}^{11}}{R_{\text {compr }}^{1}}
$$

where $d_{2} / d_{1}$ - the ratio of the vertical and horizontal dimensions of the structure blocks of rock; $R_{\text {compr }}^{11} / R_{\text {compr }}^{1}$ - the ratio of the ultimate compressive strength of rock towards the thrust of the arch and towards the influence of rock weight.

The condition of the daylight surface maintenance for the instances with rock cave-in with the development of an arch:

$$
H^{1}>h_{a}
$$

where $H^{1}$ - the depth of the upper edge of the goaf from the edge of the weathered rock and loose deposits, $\mathrm{m}$.

In case the condition is not met, the goaf requires stowing with hardening mixtures in order to meet the following condition under the reduced height of the goaf [3]:

$$
H^{1}>h_{a}=\frac{B}{2 v}=\frac{B}{4\left(d_{2} / d_{1}\right)\left(R_{\text {compr }}^{11} / R_{\text {compr }}^{1}\right)},
$$

where $h_{a}$ - the rise of the arch under partially filled goaf, $\mathrm{m}$.

The height $h_{f}$, to which the goaf should be filled, is determined according to the formula proposed by the authors [4].

Under $\alpha \geq\left(90^{\circ}+\varphi\right) / 2$

$$
h_{f}>h+\left(\frac{m}{\sin \alpha}-2 H^{1} \frac{d_{2}}{d_{1}} \cdot \frac{R_{c o m p r}^{11}}{R_{\text {compr }}^{1}}\right) \operatorname{tg} \frac{90^{\circ}+\varphi}{2} .
$$


With the negative $h_{f}$, there is no need in stowing, and the goaf is filled by the method of insulation.

$$
\begin{aligned}
& \text { Under } \alpha<\left(90^{\circ}+\varphi\right) / 2 \\
& \qquad h_{f}>h+\left(\frac{m}{\sin \alpha}-4 H^{1} \frac{d_{2}}{d_{1}} \cdot \frac{R_{c o m p r}^{11}}{R_{\text {compr }}^{1}}\right) \frac{\operatorname{tg} \alpha \operatorname{tg}\left(\left(90^{\circ}+\varphi\right) / 2\right)}{\operatorname{tg} \alpha+\operatorname{tg}\left(\left(90^{\circ}+\varphi\right) / 2\right)} .
\end{aligned}
$$

At the absence of rock self-jam, the height of cave-in expansion is determined by the degree of rock fragmentation.

The zone of hazardous rock displacement according to VNIMI, is shown at fig. 5, 6 [5-7].

If $H^{1}<h_{a}$ then the height of the stowing mass which will not cause the displacement of the surface is as follows:

$h_{f}=\frac{k h m \operatorname{tg} \alpha-H^{1}\left(K_{f}-1\right)(m \operatorname{tg} \alpha+h \sin \alpha)}{k m \operatorname{tg} \alpha-H^{1}\left(K_{f}-1\right) \sin \alpha}$,

where $h$ - the full height of the goaf including the height of the stowing mass $h_{f}, \mathrm{~m} ; m$ - the normal width of the goaf, $\mathrm{m}$; $\alpha$-inclination angle of the goaf, degrees; $k$ - safety factor; $K_{f}-$ degree of fragmentation;

$$
H^{1}=\frac{k h m \operatorname{tg} \alpha}{\left(K_{f}-1\right)(m \operatorname{tg} \alpha+h \sin \alpha)} .
$$

The condition of the stable state of the surface according to VNIMI (Temporary instructions on rock pressure control in stopes at $3.5 \mathrm{~m}$ thick layers with the angle of inclination up to 5 degrees. Vostochniy Research Institute for Mining Safety, VNIMI Skochinsky Institute of Mining, 76 p.):

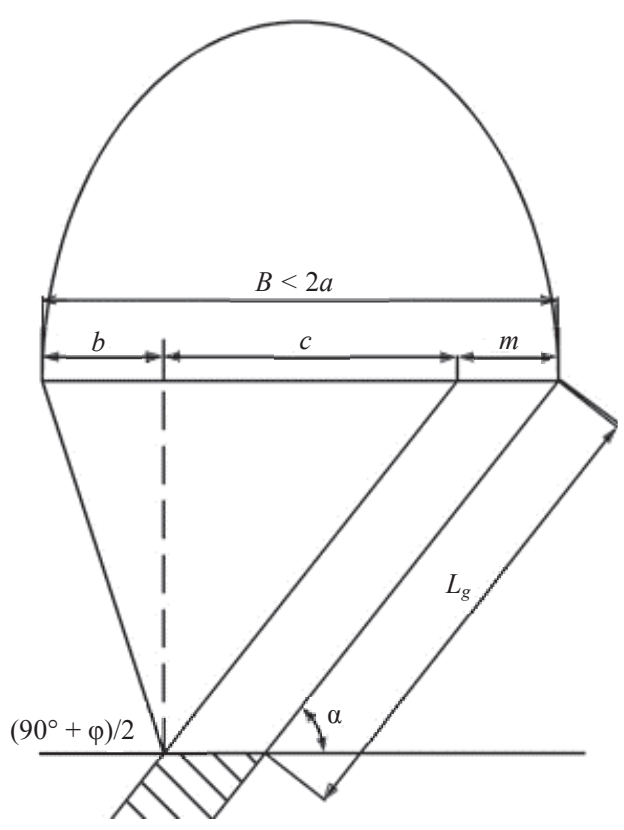

Fig. 4. Scheme for the ultimate arch of balance development condition determination at gently sloping ore body

Рис. 4. Схема к определению условия образования предельного свода равновесия при пологом падении рудного тела

$$
H^{1}>H_{f}^{1}=K_{1} l_{e q}
$$

where $H^{1}$ - the depth of the upper edge of the goaf from the weathered rock and deposits, $\mathrm{m} ; H_{f}^{1}$ - the depth of the upper edge of the goaf from the edge of the weathered rock and loose deposits, $\mathrm{m} ; K_{1}-$ the coefficient which takes into account the strength properties of rock (table 2 ); $l_{\text {eq }}$ - equivalent span;

$$
l_{e q}=\frac{L l^{1}}{\sqrt{\left(L^{2}+\left(l^{1}\right)^{2}\right)}},
$$

where $L$ - goaf length along the strike, $\mathrm{m} ; l_{1}$ - the length of goaf horizontal surface across the strike, $\mathrm{m}$. 
If $L>2 l_{1}$, then $l_{e q}=l_{1}$. If $L<2 l_{1}$, then $l_{e q}=L$.

The condition which excludes cave-in to the surface, according to VNIMI [8-9]:

$$
H^{1}=\frac{S \sin \alpha_{d}}{m_{d}},
$$

where $H^{1}$ - the depth of the mine working outline from the weathered rock and deposits, $\mathrm{m} ; S$-goaf area, $\mathrm{m}^{2} ; \alpha_{d}$ - the angle of inclination of the line of disturbance, degrees; $m_{d}-$ the thickness of the zone along with the zone of fracture and foliation, $\mathrm{m}$.

Table 1. Geotechnical characteristic of the field Таблица 1. Инженерно-геологическая характеристика месторождения

\begin{tabular}{l|c|c|c|c}
\hline \multicolumn{1}{c|}{ Site characteristic } & $\begin{array}{c}\text { Volumetric } \\
\text { weight of rock, } \\
\mathrm{t} / \mathrm{m}^{3}\end{array}$ & $\begin{array}{c}\text { Rock strength, } \\
\mathrm{kg} / \mathrm{cm}^{2}\end{array}$ & $\begin{array}{c}\text { Dimension of } \\
\text { the structure } \\
\text { block, } \mathrm{m}\end{array}$ & $\begin{array}{c}\text { Rock weakness } \\
\text { coefficient }\end{array}$ \\
\hline $\begin{array}{l}\text { Interface nodes of faults and contact } \\
\text { Zones of major faults and contacts }\end{array}$ & 2.65 & 639 & $0.4 \times 0.4$ & 0.37 \\
$\begin{array}{l}\text { Internal parts of tectonic blocks between } \\
\text { the fault and the contact }\end{array}$ & 2.65 & 587 & $0.8 \times 1.6$ & 0.43 \\
\end{tabular}

Goaf filling method selection for the assumed conditions. The depth of the mine working outline from the weathered rock and deposits $H^{1}=60 \mathrm{~m}$. The full height of the goaf including the height of the mass of the hardening mixture $h=15 \mathrm{~m}$. Actual width of the ore body $L=225 \mathrm{~m}$. The thickness of the ore body $m=6 \mathrm{~m}$. The angle of inclination of the ore body $\alpha=80^{\circ}$. Rock caving angle $\varphi=50^{\circ}$. Horizontal dimension of a structure block of rock $d_{1}=1.0 \mathrm{~m}$. Vertical dimension of a structure block of rock $d_{2}=1.0 \mathrm{~m}$. Ultimate compressive strength of a structure block $R_{\text {compr }}^{1}$ и $R_{\text {compr }}=600 \mathrm{~kg} / \mathrm{cm}^{2}$. Volumetric weight of rock $\gamma=2.7 \mathrm{t} / \mathrm{m}^{3}$.

Then the length of goaf horizontal surface across the strike is as follows:

$$
l^{1}=\frac{m}{\sin \alpha}+\frac{h}{\operatorname{tg} \alpha}=8,8 \mathrm{~m} .
$$

Goaf volume:

$$
V_{1}=L \frac{m}{\sin \alpha} h=2296 \mathrm{~m}^{3} .
$$

Goaf area:

$$
S=l^{1} L=220 \mathrm{~m}^{2}
$$

The span of the ultimate arch of rock self-jam:

$$
2 a=2 d_{1}\left(\frac{10 R_{c o m p r}^{1}}{K H \gamma}-1\right)=25,8 \mathrm{~m} .
$$

The span of the cave-in zone:

$$
B=\frac{2 h}{\operatorname{tg}\left(\left(90^{\circ}+\varphi\right) / 2\right)}+\frac{m}{\sin \alpha}=17 \mathrm{~m} .
$$


Arch development condition:

$$
2 a \geq B \quad 25,8 \mathrm{~m}>17 \mathrm{~m} .
$$

The arch develops with the safety factor $K=2$.

The height of rock self-jam arch:

$$
h_{a}=\frac{B}{4}=4,3 \mathrm{~m}
$$

Surface maintenance condition verification:

$$
H^{1}>h_{a} \cdot 60>4,3 \mathrm{~m}
$$

Consequently, the goaf may be filled with the method of insulation.

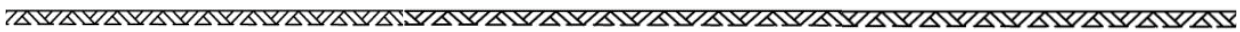
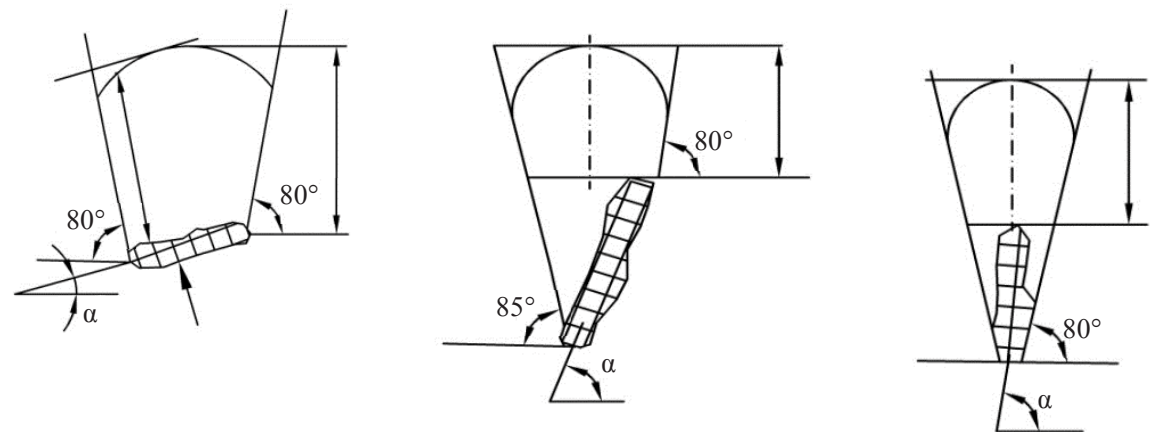

Fig. 5. Plotting the area boundaries of hazardous displacements in the rock mass at section across the strike

Рис. 5. Построение границ области опасных сдвижений в толще пород на разрезах вкрест простирания

Goaf filling method selection when the conditions are changed.

The height of the artificial mass made of the stowage material:

$$
h_{f}=\frac{k h m \operatorname{tg} \alpha-H^{1}\left(K_{f}-1\right) \cdot(m \operatorname{tg} \alpha+h \sin \alpha)}{k m \operatorname{tg} \alpha-H^{1}\left(K_{f}-1\right) \sin \alpha}=4,6 \mathrm{~m} .
$$

For further calculation $7 \mathrm{~m}$ is accepted. The remaining $8 \mathrm{~m}$ height void is filled with the method of insulation. The height of the insulated site:

$$
H^{1}=h_{a}^{1} \cdot 60=49 \mathrm{~m}
$$

Verification by VNIMI formula:

$$
H^{1}>H_{f}^{1}=K_{1} l_{e q} .
$$


Under the tabular value of $K_{1}=9.0$

$$
\begin{gathered}
l_{e q}=\frac{L l_{1}}{\sqrt{\left(L^{2}+l_{1}^{2}\right)}}=8,3 \mathrm{~m} ; \\
H^{1}<H_{f}^{1} ; H^{1}=60 \mathrm{~m} ; H_{f}^{1}=75 \mathrm{~m} .
\end{gathered}
$$

Among $49 \mathrm{~m}$ and $75 \mathrm{~m}$ the safest is accepted, i. e. $49 \mathrm{~m}$.
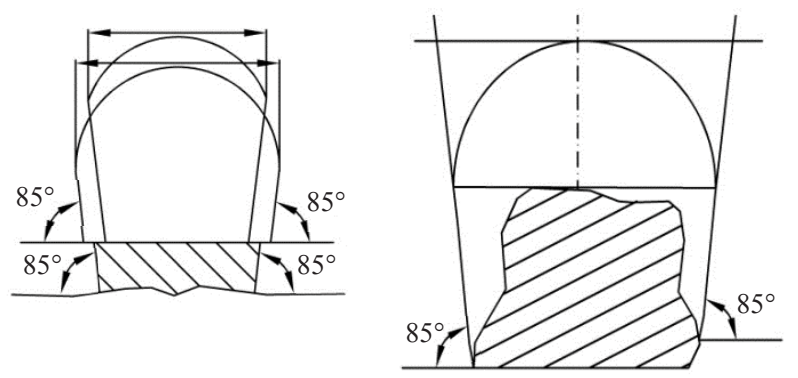

Fig. 6. Plotting the area boundaries of hazardous displacements

in the rock mass longitudinally

Рис. 6. Построение границ области опасных сдвижений в толще пород в вертикальной проекции

Goaf filling method selection when $3 \mathrm{~m}$ thick highly-disturbed rock zone with $80^{\circ}$ inclination angle of disturbance and capable of running into the mine working is uncovered by the mine working:

$$
H^{1}=\frac{S \sin \alpha_{d}}{m_{d}}=150 \mathrm{~m}
$$

The calculation determined the need for the partial stowing of the goaf. The remaining void, not more than $5 \mathrm{~m}$ high, is filled with insulation. Research results correspond with the results of the similar international investigations [8-13].

Table 2. Values of $K_{1}$ coefficient

Таблица 2. Значения коэффициента $K_{1}$

\begin{tabular}{c|c|c|c|c|c|c|c|c|c|c}
\hline Strength coefficient & 4 & 5 & 6 & 7 & 8 & 9 & 10 & 12 & 14 & 16 \\
\hline$K_{1}$ & 9.0 & 6.8 & 5.3 & 4.4 & 3.7 & 5.2 & 2.8 & 2.2 & 1.8 & 1.6
\end{tabular}

Conclusion. The application of discrete rock jam phenomenon with the implementation of its residual strength is a workable trend in goaf filling technology improvement when mining hard rock deposits, which makes it possible to obtain an environmental and economic effect while ensuring the safety of mining.

\section{REFERENCES}

1. Golik V. I., Polukhin O. N. Environmental geotechnologies in mining. Belgorod; 2013. (In Russ.)

2. Razorenov Iu. I., Golik V. I., Kulikov M. M. Mining management and economics. Ministry of Education and Science of the Russian Federation, Platov South-Russian State Polytechnic University. Novocherkassk; 2010. (In Russ.) 
3. Golik V. I., Doolin A. N., Komissarova M. A., Doolin R. A. Evaluating the effectiveness of utilization of mining waste. International Business Management. 2015; 9 (6): 1119-1123.

4. Golik V., Komashchenko V., Morkun V., Burdzieva O. Metal deposits combined development experience. Metallurgical and Mining Industry. 2015; 7 (6): 591-594.

5. Golik V. I. Optimization of thin flat ore bodies development technologies at geomechanical basis. Izvestiia Tulskogo gosudarstvennogo universiteta. Nauki o Zemle = Proceedings of the Tula State University. Sciences of Earth. 2016; 4: 139-152. (In Russ.)

6. Liashenko V. I., Golik V. I. Methods of geomechanical monitoring of rock mass for underground mining. Gornyi zhurnal = Mining Journal. 2004; 5: 47-50. (In Russ.)

7. Dmitrak Iu. V., Golik V. I., Dzeranov B. V. The preservation of the Earth's surface from destruction at underground mining of ores. Izvestiia Tulskogo gosudarstvennogo universiteta. Nauki o Zemle = Proceedings of the Tula State University. Sciences of Earth. 2018; 1: 12-22. (In Russ.)

8. Komashchenko V. I., Vasilev P. V., Maslennikov S. A. Dependable raw materials base for underground mining the KMA deposits. Izvestiia Tulskogo gosudarstvennogo universiteta. Nauki o Zemle = Proceedings of the Tula State University. Sciences of Earth. 2016; 2: 101-114. (In Russ.)

9. Golik V., Komashchenko V., Morkun V., Zaalishvili V. Enhancement of lost ore production efficiency by usage of canopies. Metallurgical and Mining Industry. 2015; 7 (4): 325-329. (In Russ.)

10. Dold B., Weibel L. Biogeometallurgical pre-mining characterization of ore deposits: An approach to increase sustainability in the mining process. Environmental Science and Pollution Research. 2013; 20 (11): 7777-7786.

11. Khani A., Baghbanan A., Norouzi S., Hashemolhosseini H. Effects of fracture geometry and stress on the strength of a fractured rock mass. International Journal of Rock Mechanics \& Mining Sciences. 2013; 60: 345-352.

12. Oraee-Mirzamani K., Ping Y. J., Zhong C. W., Sen Y. D., Qiang Y. J. Numerical determination of strength and deformability of fractured rock mass by FEM modeling. Computers and Geotechnics. 2015; 64: 20-31.

13. Latyshev O. G., Frants V. V. Stability estimation of rock mass weakened by fissure. Izvestiya vysshikh uchebnykh zavedenii. Gornyi zhurnal = News of the Higher Institutions. Mining Journal. 2018; 1: 36-42.

Received 14 August 2019

\section{Information about authors:}

Vladimir I. Golik - DSc (Engineering), Professor, professor of Mining Department, North Caucasian Institute of Mining and Metallurgy (State Technological University). E-mail: v.i.golik@mail.ru

Niiaz G. Valiev - DSc (Engineering), Professor, Head of Mining Department, Ural State Mining University. E-mail: niyaz.valiev@m.ursmu.ru

Iurii I. Razorenov - DSc (Engineering), Professor, acting rector, Platov South-Russian State Polytechnic University. E-mail: yiri1963@mail.ru

Viktor G. Lukianov - DSc (Engineering), Professor, professor of the Department of Oil Storage and Transportation, Institute of Natural Resources, National Research Tomsk Polytechnic University. E-mail: lukyanov@tpu.ru

Stanislav A. Maslennikov - PhD (Engineering), Associate Professor, Head of the Department of Construction and Technosphere Safety, Institute of Service and Business (branch), Don State Technical University. E-mail: doc_zamdirnir@sssu.ru

DOI: $10.21440 / 0536-1028-2020-1-25-35$

\section{Обоснование способа погашения выработанного пространства с использованием феномена заклинивания пород}

Голик В. И. ${ }^{1}$, Валиев Н. Г. ${ }^{2}$, Разоренов Ю. И. ${ }^{3}$, Лукьянов В. Г. ${ }^{4}$, Масленников С. А. $^{5}$

${ }^{1}$ Северо-Кавказский государственный технологический университет, Владикавказ, Россия.

2 Уральский государственный горный университет, Екатеринбург, Россия.

3 Южно-Российский государственный политехнический университет, Новочеркасск, Россия.

${ }^{4}$ Национальный исследовательский Томский политехнический университет, Томск, Россия.

5 Донской государственный технический университет (филиал), Шахты Ростовской обл., Россия.

\section{Peфepam}

Предмет, тема, цель работы. Детализация механизма заклинивания дискретных пород скальных массивов с реализацией их остаточной прочности для оптимизации процессов погашения выработанного пространства.

Методология проведения работы. Применение положений строительной механики и механики сплошной среды для объяснения и совершенствования методов использования механизма реализации остаточной прочности дискретных пород в результате заклинивания при расчете параметров управления состоянием рудовмещаюючего массива. 
Результаты работы и область их применения. Дана характеристика концепции погашения выработанного пространства при подземной разработке структурно нарушенных месторождений. Приведены сведения о геологическом строении исследуемого месторождения скальных руд и роли тектонических структур в поведении массива при его разработке. Показаны результаты исследования состояния массива с выделением в его составе инженерно-геологических участков по признаку ослабленности пород. Рассмотрены варианты поведения рудовмещающего массива в зависимости от феномена самозаклинивания элементарных структурных блоков пород. Обоснованы возможности погашения выработанного пространства при комбинировании способов погашения изоляцией и закладкой твердеющцими смесями. Рекомендована область применения результатов исследования при разработке месторождений твердых полезных ископаемых подземным способом.

Выводы. Использование расчетных методов при реализации остаточной прочности дискретных пород в результате их заклинивания путем использования свойства заклинивания дискретных пород является пока еще мало используемым фактором технологии погашения выработанного пространства, обеспечивающим возможность получения эколого-экономического эффекта при обеспечении безопасности горных работ.

Ключевые слова: порода; прочность; погашение; выработанное пространство; заклинивание; управление; безопасность.

В статье представлены результаты исследований, выполненных по программе Еrasmus + 574061-EPP-1-2016-1-DE-EPPKA2-CBHE-JP “Modernization of geological education in Russian and Vietnamese universities".

\section{БИБЛИОГРАФИЧЕСКИЙ СПИСОК}

1. Голик В. И., Полухин О. Н. Природоохранные геотехнологии в горном деле. Белгород, 2013. $280 \mathrm{c}$.

2. Разоренов Ю. И., Голик В. И., Куликов М. М. Экономика и менеджмент горной промышленности / Министерство образования и науки Российской Федерации, Южно-Российский государственный политехнический университет. Новочеркасск, 2010. 244 с.

3. Golik V. I., Doolin A. N., Komissarova M. A., Doolin R. A. Evaluating the effectiveness of utilization of mining waste // International Business Management. 2015. Vol. 9. No. 6. P. 1119-1123.

4. Golik V., Komashchenko V., Morkun V., Burdzieva O. Metal deposits combined development experience // Metallurgical and Mining Industry. 2015. Vol. 7. No. 6. P. 591-594.

5. Голик В. И. Оптимизация технологии разработки маломощных пологих рудных тел на геомеханической основе // Известия Тульского государственного университета. Науки о Земле. 2016. № 4. C. 139-152.

6. Ляшенко В. И., Голик В. И. Средства геомеханического мониторинга породного массива при подземной разработке рудных месторождений // Горный журнал. 2004. № 5. С. 47-50.

7. Дмитрак Ю. В., Голик В. И., Дзеранов Б. В. Сохранение земной поверхности от разрушения при подземной добыче руд // Известия Тульского государственного университета. Науки о Земле. 2018. № 1. C. 12-22.

8. Комащенко В. И., Васильев П. В., Масленников С. А. Технологиям подземной разработки месторождений КМА - надежную сырьевую основу // Известия Тульского государственного университета. Науки о Земле. 2016. № 2. С. 101-114.

9. Golik V., Komashchenko V., Morkun V., Zaalishvili V. Enhancement of lost ore production efficiency by usage of canopies // Metallurgical and Mining Industry. 2015. Vol. 7. No. 4. P. 325-329.

10. Dold B., Weibel L. Biogeometallurgical pre-mining characterization of ore deposits: An approach to increase sustainability in the mining process // Environmental Science and Pollution Research. 2013. Vol. 20. No. 11. P. 7777-7786.

11. Khani A., Baghbanan A., Norouzi S., Hashemolhosseini H. Effects of fracture geometry and stress on the strength of a fractured rock mass // International Journal of Rock Mechanics \& Mining Sciences. 2013. No. 60. P. 345-352.

12. Oraee-Mirzamani K., Ping Y. J., Zhong C. W., Sen Y. D., Qiang Y. J. Numerical determination of strength and deformability of fractured rock mass by FEM modeling // Computers and Geotechnics. 2015. Vol. 64. P. 20-31.

13. Латышев О. Г., Франц В. В. Оценка устойчивости породного массива, ослабленного трещиной // Известия вузов. Горный журнал. 2018. № 1. С. 36-42.

Поступила в редакцию 14 августа 2019 года

\section{Сведения об авторах:}

Голик Владимир Иванович - доктор технических наук, профессор, профессор кафедры горного дела Северо-Кавказского государственного технологического университета. E-mail: v.i.golik@mail.ru

Валиев Нияз Гадым Оглы - доктор технических наук, профессор, заведующий кафедрой горного дела Уральского государственного горного университета. E-mail: niyaz.valiev@m.ursmu.ru 
Разоренов Юрий Иванович - доктор технических наук, профессор, и. о. ректора Южно-Российского государственного политехнического университета. E-mail: yiri1963@mail.ru

Лукьянов Виктор Григорьевич - доктор технических наук, профессор, профессор кафедры транспорта и хранения нефти Института природных ресурсов Национального исследовательского Томского политехнического университета. E-mail: lukyanov@tpu.ru

Масленников Станислав Александрович - кандидат технических наук, доцент, заведующий кафедрой строительства и техносферной безопасности Института сферы обслуживания и предпринимательства (филиал) Донского государственного технического университета. E-mail: doc_zamdirnir@sssu.ru

Для цитирования: Голик В. И., Валиев Н. Г., Разоренов Ю. И., Лукьянов В. Г., Масленников С. А. Обоснование способа погашения выработанного пространства с использованием феномена заклинивания пород // Известия вузов. Горный журнал. 2020. № 1. С. 25-35 (In Eng.). DOI: 10.21440/05361028-2020-1-25-35

For citation: Golik V. I., Valiev N. G., Razorenov Iu. I., Lukianov V. G., Maslennikov S. A. Substantiating the method of filling the goaf using the rock jam phenomenon. Izvestiya vysshikh uchebnykh zavedenii. Gornyi zhurnal $=$ News of the Higher Institutions. Mining Journal. 2020; 1: 25-35. DOI: 10.21440/05361028-2020-1-25-35 